\title{
Synthesis, Crystal Structure, Resistivity, and Electronic Structure of the U(V) Quaternary Polyselenide $\mathrm{Ba}_{8} \mathrm{PdU}_{2} \mathrm{Se}_{12}\left(\mathrm{Se}_{2}\right)_{2}$
}

\author{
Jai Prakash, ${ }^{\text {a }}$ Adel Mesbah, ${ }^{\text {a,b }}$ Sébastien Lebègue, ${ }^{\mathrm{c}}$ Christos D. Malliakas, ${ }^{\mathrm{a}}$ and James A. \\ Ibers $^{\mathrm{a}, *}$ \\ ${ }^{a}$ Department of Chemistry, Northwestern University, Evanston, IL 60208-3113, USA \\ ${ }^{b}$ ICSM, UMR 5257 CEA / CNRS / UM2 / ENSCM, Site de Marcoule - Bât. 426, BP 17171, 30207 Bagnols-sur-Cèze \\ cedex, France \\ ${ }^{c}$ Laboratoire de Cristallographie, Résonance Magnétique et Modélisations (CRM2, UMR CNRS 7036),Institut Jean \\ Barriol, Université de Lorraine, BP 239, Boulevard des Aiguillettes, 54506 Vandoeuvre-lès-Nancy, France
}

Keywords: uranium(V)selenide; synthesis; crystal structure; resistivity studies

\begin{abstract}
A new quaternary uranium (V) selenide, $\mathrm{Ba}_{8} \mathrm{PdU}_{2} \mathrm{Se}_{12}\left(\mathrm{Se}_{2}\right)_{2}$, has been synthesized by reaction of elements at 1173 $\mathrm{K}$. A single-crystal X-ray diffraction study shows that the compound crystallizes in a new structure type with two formula units in space group $D_{2 h}^{12}-$ Pnnm of the orthorhombic crystal system with cell constants of $a=9.490(1), b=$ $12.240(2)$, and $c=13.780(3) \AA$. Its crystal structure consists of $\left[\mathrm{PdU}_{2} \mathrm{Se}_{12}{ }^{12-}\right]$ units where $\mathrm{U}$ atoms are coordinated to six Se atoms in octahedral geometry and $\mathrm{Pd}$ atoms are coordinated to four Se atoms in square-planar geometry. These $\left[\mathrm{PdU}_{2} \mathrm{Se}_{12}{ }^{12-}\right]$ units are separated by $\mathrm{Ba}$ to result in a salt-like crystal structure. This compound also contains $\mathrm{Se}_{2}{ }^{2-}$ dimers that are part of $\mathrm{Ba}$ coordination polyhedra. The formula charge balances as $\left(\mathrm{Ba}^{2+}\right)_{8}\left(\mathrm{Pd}^{2+}\right)\left(\mathrm{U}^{5+}\right)_{2}\left(\mathrm{Se}^{2-}\right)_{12}\left(\mathrm{Se}_{2}^{2-}\right)_{2}$. Theoretical calculations predict antiferromagnetic semiconducting behavior for this compound with a band gap of $1.6 \mathrm{eV}$. Temperature-dependent four-probe resistivity measurements on single crystal confirm semiconducting nature with an activation energy of $0.18(1) \mathrm{eV}$.
\end{abstract}

\section{Introduction}

*Corresponding author. Fax: +1 8474912976

E-mail address: ibers@chem.northwestern.edu (J.A.Ibers) 
Ternary and quaternary solid state compounds of alkali $(A)$ or alkaline earth metals $(A k)$, actinides $(A n)$, transition metals $(M)$, and chalcogens $(Q)$ display a variety of interesting physical properties, such as superconductivity [1,2], magnetism [3-5], and charge density waves [6], owing to interactions of $5 f$-electrons of actinide and $d$-electrons of transition metals. These compounds also show interesting crystal structures because of the tendency of actinides and transition metals to show variable oxidation states and chalcogens to show various $Q-Q$ interactions.

The crystal structures of most of these compounds are formed by sharing of actinide polyhedra and transition metals polyhedra; $A / A k$ atoms separate these $M_{x} A n_{y} Q_{z}$ units thereby guiding the overall dimensionality of the structure. In general, $A n$ atoms in these structures have either bicapped trigonal-prismatic or octahedral coordination whereas the $M$ atoms are in octahedral, tetrahedral, or square-planar coordination depending on the oxidation state and nature of the transition metal. Indeed, as has been discussed, these structures can be manipulated by judicious choice of the coordination preferences of the metal [7].

There are relatively few quaternary actinide chalcogenides with transition metals as compared with related ternary compounds. Some examples include $A_{2} M_{3} \mathrm{U} Q_{6}(A=\mathrm{K}, \mathrm{Rb}, \mathrm{Cs} ; M$ $=\mathrm{Pd}, \mathrm{Pt} ; Q=\mathrm{S}, \mathrm{Se}$ ) [8], $\mathrm{Ba}_{8} \mathrm{Hg}_{3} \mathrm{U}_{3} \mathrm{~S}_{18}$ [9], $\mathrm{Cs}_{2} \mathrm{Hg}_{2} \mathrm{USe}_{5}$ [10], $\mathrm{CsCuUSe}_{3}$ [11], $\mathrm{Ba}_{4} \mathrm{Cr}_{2} \mathrm{US}_{9}$ [12], $A_{6} \mathrm{Cu}_{12} \mathrm{U}_{2} \mathrm{~S}_{15}(A=\mathrm{K}, \mathrm{Rb}, \mathrm{Cs})$ [13], $A_{2} M_{4} \mathrm{U}_{6} Q_{17}(A=\mathrm{Cs}, \mathrm{Rb} ; M=\mathrm{Pt}, \mathrm{Pd} ; Q=\mathrm{S}, \mathrm{Se})$ [14], $\mathrm{Tl}_{3} \mathrm{Cu}_{4} \mathrm{USe}_{6}$ [15], $\mathrm{Tl}_{2} \mathrm{Ag}_{2} \mathrm{USe}_{4}$ [15], $\mathrm{Ba}_{2} \mathrm{Cu}_{4} \mathrm{USe}_{6}$ [16], $A k_{2} \mathrm{Cu}_{2} A n Q_{5}(A k=\mathrm{Ba}, \mathrm{Sr} ; A n=\mathrm{Th}, \mathrm{U} ; Q$ $=\mathrm{S}$, Se) [16-18], $\mathrm{CsUMTe}_{5}\left(M=\mathrm{Ti}\right.$ [19] and $\mathrm{Zr}$ [20]), $A \mathrm{TiU}_{3} \mathrm{Te}_{9}(A=\mathrm{Rb}, \mathrm{Cs})$ [21], $\mathrm{Cs}_{5} \mathrm{Hf}_{5} \mathrm{UTe}_{30.6}$ [19], $\mathrm{Ba}_{2} M A n \mathrm{Te}_{7}(M=\mathrm{Ti}, \mathrm{Cr} ; A n=\mathrm{Th}, \mathrm{U})$ [22], and $A M \mathrm{UQ}_{3}(A=\mathrm{Rb}, \mathrm{Cs})[23]$.

The chemistry of these uranium chalcogenides is dominated by $\mathrm{U}^{4+}$ compounds. However, there are a very few compounds of $\mathrm{U}^{3+}$ or $\mathrm{U}^{5+}$. Examples of $\mathrm{U}^{3+}$ compounds include $\mathrm{ScUS}_{3}$ [24], $\mathrm{ScU}_{3} \mathrm{~S}_{6}$ [25]; examples of $\mathrm{U}^{5+}$ compounds include $\mathrm{Tl}_{3} \mathrm{Cu}_{4} \mathrm{USe}_{6}$ [15], $\mathrm{Ba}_{9} \mathrm{Ag}_{10} \mathrm{U}_{4} \mathrm{~S}_{24}$ [26], $\mathrm{Ba}_{3} \mathrm{AgUS}_{6}$ [27], and $\mathrm{K}_{2} \mathrm{Cu}_{3} \mathrm{US}_{5}$ [28]. Here we present the synthesis, crystal structure, resistivity, and electronic calculations for the new quaternary $\mathrm{U}^{5+}$ selenide $\mathrm{Ba}_{8} \mathrm{PdU}_{2} \mathrm{Se}_{12}\left(\mathrm{Se}_{2}\right)_{2}$ discovered by exploratory synthesis.

\section{Experimental}




\subsection{Synthesis of $\mathrm{Ba}_{8} \mathrm{Pd} U_{2} \mathrm{Se}_{12}\left(\mathrm{Se}_{2}\right)_{2}$}

The starting materials Ba (Johnson Matthey, 99.5\%), Pd (Aldrich, $99.9 \%$ ), and Se (Cerac, 99.999\%) were used as obtained. Reactions were performed in sealed $6 \mathrm{~mm}$ carboncoated fused-silica tubes. Depleted U powder was obtained by hydridization and decomposition of uranium turnings (IBI Labs) in a modification [29] of a previous literature method [30]. Chemical manipulations were performed inside an Ar-filled dry box. The reactants were weighed and transferred into tubes that were then evacuated to $10^{-4}$ Torr, flame sealed, and placed in a computer-controlled furnace. Semi-quantitative energy-dispersive X-ray analyses (EDX) of the products of the reaction were obtained with the use of a Hitachi S-3400 scanning electron microscope (SEM).

Crystals of $\mathrm{Ba}_{8} \mathrm{PdU}_{2} \mathrm{Se}_{12}\left(\mathrm{Se}_{2}\right)_{2}$ were obtained from the reaction of $\mathrm{Ba}$ (46.2 $\mathrm{mg}, 0.336$ mmol), U (10 mg, $0.042 \mathrm{mmol}), \mathrm{Pd}(8.9 \mathrm{mg}, 0.084 \mathrm{mmol})$, and Se (53.1 mg, $0.672 \mathrm{mmol})$. The reaction mixture was heated to1073 $\mathrm{K}$ in $36 \mathrm{~h}$ and held there for $15 \mathrm{~h}$. Next it was heated to 1173 $\mathrm{K}$ in $24 \mathrm{~h}$ and held there for $198 \mathrm{~h}$. Then it was cooled to $973 \mathrm{~K}$ at $2 \mathrm{~K} / \mathrm{h}$ and to $573 \mathrm{~K}$ at $4 \mathrm{~K} / \mathrm{h}$ before the furnace was turned off. The reaction product contained black block-shaped crystals of $\mathrm{Ba}_{8} \mathrm{PdU}_{2} \mathrm{Se}_{16}(\mathrm{Ba}: \mathrm{Pd}: \mathrm{U}: \mathrm{Se} \approx 8: 1: 2: 16)$, red crystals of BaSe $(\mathrm{Ba}: \mathrm{Se} \approx 1: 1), \operatorname{PdSe}(\mathrm{Pd}: \mathrm{Se} \approx 1: 1)$ [31], and plates of UOSe [32].

\subsection{Structure determination}

The crystal structure of $\mathrm{Ba}_{8} \mathrm{PdU}_{2} \mathrm{Se}_{12}\left(\mathrm{Se}_{2}\right)_{2}$ was determined from single-crystal X-ray diffraction data collected with the use of graphite-monochromatized $\operatorname{MoK} \alpha$ radiation $(\lambda=$ $0.71073 \AA$ ) at $100(2) \mathrm{K}$ on a Bruker APEX2 diffractometer [33]. The algorithm COSMO implemented in the program APEX2 was used to establish the data collection strategy with a series of $0.3^{\circ}$ scans in $\omega$ and $\varphi$. The exposure time was $10 \mathrm{~s} /$ frame and the crystal-to-detector distance was $60 \mathrm{~mm}$. The collection of intensity data as well as cell refinement and data reduction were carried out with the use of the program APEX2 [33]. Face-indexed absorption, incident beam, and decay corrections were performed with the use of the program SADABS 
[34]. Precession images derived from the data set provided no evidence for a super cell or modulation. The structure was solved and refined in a straightforward manner with the use of the SHELX-14 algorithms of the SHELXT program package [34,35]. The program STRUCTURE TIDY [36] in PLATON [37] was used to standardize the atomic positions. Further details are given in Table 1 and in the Supporting Information.

\subsection{Resistivity study}

Four-probe temperature-dependent resistivity data were collected using a home-made resistivity apparatus equipped with a Keithley 2182 nanovoltmeter, a Keithley 236 source measure unit, and a high-temperature vacuum chamber controlled by a K-20 MMR system. An I-

$V$ curve from $1 \times 10^{-5} \mathrm{~A}$ to $-1 \times 10^{-5} \mathrm{~A}$ with a step of $2 \times 10^{-6} \mathrm{~A}$ was measured for each temperature point and resistance was calculated from the slope of the $I-V$ plot. Data acquisition was controlled by custom-written software. Graphite paint (PELCO isopropanol-based graphite paint) was used for electrical contacts with $\mathrm{Cu}$ of $0.025 \mathrm{~mm}$ thickness (Omega). Direct current was applied along an arbitrary direction.

\subsection{Theoretical Calculations}

Calculations have been performed with the VASP (Vienna ab Initio Simulation Package) [38,39] implementing density functional theory [40,41] with the PAW (projector augmented wave) method [42]. The exchange-correlation potential of Heyd-Scuseria-Ernzerhof (HSE) [4345] was used in its spin polarized version. The atom positions and cell parameters were taken from the experimental results. The various possible magnetic orders that can occur in the crystallographic cell of $\mathrm{Ba}_{8} \mathrm{PdU}_{2} \mathrm{Se}_{16}$ were calculated and the one with the lowest total energy was retained as the ground state. Also, a $k$-point mesh of $4 \times 4 \times 4$ to sample the Brillouin zone and the default cut-off for the plane-wave part of the wave function were used.

\section{Results}




\subsection{Synthesis}

Black single crystals of $\mathrm{Ba}_{8} \mathrm{PdU}_{2} \mathrm{Se}_{16}$ were obtained by reaction of elements at $1173 \mathrm{~K}$ in a yield of about $40 \mathrm{wt} \%$ based on U. Secondary byproducts were BaSe, PdSe [31], and UOSe [32]. UOSe resulted from the etching of the fused-silica tube. Crystals of $\mathrm{Ba}_{8} \mathrm{PdU}_{2} \mathrm{Se}_{16}$ could not be separated completely from those of UOSe nor could large single crystals of $\mathrm{Ba}_{8} \mathrm{PdU}_{2} \mathrm{Se}_{16}$ be obtained. Consequently, the magnetic properties of $\mathrm{Ba}_{8} \mathrm{PdU}_{2} \mathrm{Se}_{16}$ could not be measured.

\subsection{Crystal Structure}

The crystal structure of $\mathrm{Ba}_{8} \mathrm{PdU}_{2} \mathrm{Se}_{12}\left(\mathrm{Se}_{2}\right)_{2}$ is presented in Fig. 1 and metical data are given in Table 2. The compound crystallizes in a new structure type with two formula units in the space group $D_{2 h}^{12}-P n n m$ of the orthorhombic crystal system. There are ten independent atoms in the asymmetric unit of the crystal structure: one $U$ atom (site symmetry: ..2), one Pd atom $(.2 / m)$, three $\mathrm{Ba}$ atoms $(\mathrm{Ba} 1(1), \mathrm{Ba} 2(. . m)$, and $\mathrm{Ba} 3(. . m))$, and five $\mathrm{Se}$ atoms (Se1(1), Se2(1), $\mathrm{Se} 3(1), \operatorname{Se} 4(. . m)$, and $\mathrm{Se} 5(. . m))$. The salt-like structure consists of centrosymmetric $\left[\mathrm{PdU}_{2} \mathrm{Se}_{12}{ }^{12-}\right]$ units separated by $\mathrm{Ba}^{2+}$ cations and $\mathrm{Se}_{2}{ }^{2-}$ units. Each $\mathrm{U}$ atom in the $\left[\mathrm{PdU}_{2} \mathrm{Se}_{12}{ }^{12-}\right]$ unit is octahedrally coordinated to six Se atoms (two Se1, two Se2, and two Se3) whereas the Pd atom is coordinated to four Se1 atoms in a square-planar geometry by sharing one edge of the each $\mathrm{USe}_{6}$ octahedra (Fig. 2).

The Se4-Se4 and Se5-Se5 single bonds in the structure of 2.392(1) and 2.407(1) $\AA$ are slightly longer than the $\mathrm{Se}-\mathrm{Se}$ single bonds of $\mathrm{Se}_{2}{ }^{2-}$ units present in compounds such as

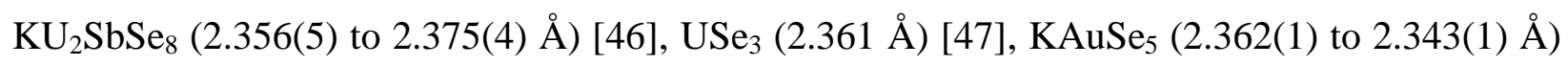
[48], $\mathrm{Cs}_{4} \mathrm{Ge}_{2} \mathrm{Se}_{8}\left(2.350 \AA\right.$ ) [49], $\mathrm{CsAuSe}_{3}\left(2.384 \AA\right.$ ) [50], and $\mathrm{RbPdCu}\left(\mathrm{Se}_{2}\right)\left(\mathrm{Se}_{3}\right)(2.338(2) \AA)$ [51]. U-Se distances (2.6873(6) to 2.8023(7) $\AA$ ) in $\mathrm{Ba}_{8} \mathrm{U}_{2} \mathrm{PdSe}_{16}$ are consistent with $\mathrm{U}^{5+}-\mathrm{Se}$ distances found in the other known $\mathrm{U}^{5+}$ selenide $\mathrm{Tl}_{3} \mathrm{Cu}_{4} \mathrm{USe}_{6}$ (Table 3). These distances are generally shorter than the $\mathrm{U}^{4+}-$ Se distances in related compounds (Table 3 ). The Pd-Se distance of 2.5031(6) $\AA$ is comparable with $\mathrm{Pd}^{2+}-$ Se distances in related the structures of compounds such

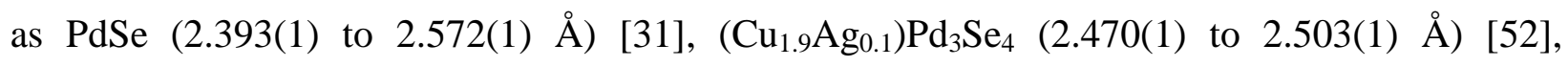

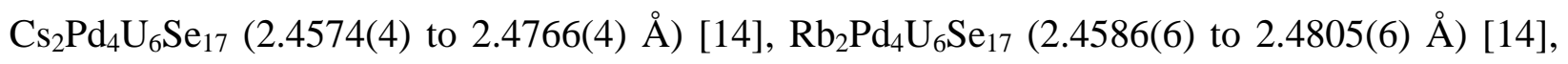


$\mathrm{Cs}_{2} \mathrm{Pd}_{3} \mathrm{Se}_{4}$ (2.457(1) to 2.460(1) $\AA$ ) [53], $\mathrm{Nb}_{2} \mathrm{Pd}_{3} \mathrm{Se}_{8}$ (2.417(2) to 2.457(2) $\AA$ ) [54], and $A \mathrm{PdCu}\left(\mathrm{Se}_{2}\right)\left(\mathrm{Se}_{3}\right)(2.4515(9)$ to 2.458(1) $\AA$; $A=\mathrm{K}, \mathrm{Rb})$ [51]. Ba1 and $\mathrm{Ba} 3$ atoms are coordinated to nine $\mathrm{Se}$ atoms while the $\mathrm{Ba} 2$ atom is coordinated to eight $\mathrm{Se}$ atoms. The $\mathrm{Ba}-\mathrm{Se}$ distances are in the range of 3.163(1) to 3.711(1) $\AA$ are as expected.

Charge balance in $\mathrm{Ba}_{8} \mathrm{PdU}_{2} \mathrm{Se}_{12}\left(\mathrm{Se}_{2}\right)_{2}$ is achieved as : $8 \times \mathrm{Ba}^{2+}, 1 \times \mathrm{Pd}^{2+}, 2 \times \mathrm{U}^{5+}, 12 \times$ $\mathrm{Se}^{2-}$, and $2 \times \mathrm{Se}_{2}{ }^{2-}$. The assignment of +2 to $\mathrm{Pd}$ is based on the propensity of $\mathrm{Pd}^{2+}$ to be in square-planar geometry as found here; in contrast $\mathrm{Pd}^{4+}$ favors octahedral geometry. The assignment of +5 to $\mathrm{U}$ is based on the data presented in Table 3 .

\subsection{Resistivity study}

The resistivity measured on a $\mathrm{Ba}_{8} \mathrm{PdU}_{2} \mathrm{Se}_{12}\left(\mathrm{Se}_{2}\right)_{2}$ single crystal decreases with increasing temperature (Fig. 4) indicative of semiconducting behavior. Resistivity at $300 \mathrm{~K}$ is around 1,200 $\Omega \mathrm{cm}$ and at $500 \mathrm{~K}$ it is around $80 \Omega \mathrm{cm}$. The corresponding activation energy estimated from the Arrhenius plot is 0.18(1) eV.

\subsection{DFT Calculations}

The computed total and partial density of states of $\mathrm{Ba}_{8} \mathrm{PdU}_{2} \mathrm{Se}_{12}\left(\mathrm{Se}_{2}\right)_{2}$ are presented in Fig. 5. We found this compound to be antiferromagnetic, as seen from the total density of states (upper plot of Fig. 5). It is a semiconductor with a band gap of $1.6 \mathrm{eV}$. The magnetic moments on the $\mathrm{U}$ atoms are seen clearly from the corresponding partial density of states (PDOS), which is highly unsymmetric with respect to the spin. These magnetic moments induce a small spin polarization on some neighboring atoms, as seen best from the PDOS of some Se atoms. Also, the top of the valence states consists mainly of U-f and Se-p states, while the bottom of the conduction states corresponds to U-f, Se-p, and Pd-d states.

\section{Conclusions}

$\mathrm{Ba}_{8} \mathrm{PdU}_{2} \mathrm{Se}_{12}\left(\mathrm{Se}_{2}\right)_{2}$, synthesized by reaction of elements at $1173 \mathrm{~K}$ is another example of 
a $\mathrm{U}(\mathrm{V})$ compound. It crystallizes in a new structure type with two formula units in space group $D_{2 h}^{12}$-Pnnm of the orthorhombic crystal system with cell constants of $a=9.490(1), b=12.240(2)$, and $c=13.780(3) \AA$. Its crystal structure is salt-like and consists of $\left[\mathrm{PdU}_{2} \mathrm{Se}_{12}{ }^{12-}\right]$ units, $\mathrm{Ba}^{2+}$ cations, and $\mathrm{Se}_{2}{ }^{2-}$ dimers. $\mathrm{U}$ atoms are coordinated to six Se atoms in octahedral geometry and $\mathrm{Pd}$ atoms are coordinated to four Se atoms in square-planar geometry. The formula charge balances as $\left(\mathrm{Ba}^{2+}\right)_{8}\left(\mathrm{Pd}^{2+}\right)\left(\mathrm{U}^{5+}\right)_{2}\left(\mathrm{Se}^{2-}\right)_{12}\left(\mathrm{Se}_{2}{ }^{2-}\right)_{2}$. Temperature-dependent four-probe resistivity measurements on a single crystal indicate that $\mathrm{Ba}_{8} \mathrm{PdU}_{2} \mathrm{Se}_{12}\left(\mathrm{Se}_{2}\right)_{2}$ is a semiconductor with an activation energy of $0.18(1) \mathrm{eV}$. Theoretical calculations predict antiferromagnetic semiconducting behavior for this compound with a band gap of $1.6 \mathrm{eV}$. The magnetic moments on the $\mathrm{U}$ atoms are seen clearly from the corresponding partial density of states (PDOS), which are highly unsymmetric with respect to the spin. The top of the valence states consists mainly of U-f and Se-p states, while the bottom of the conduction states corresponds to U-f, Se-p, and Pd-d states.

\section{Acknowledgments}

Use was made of the IMSERC X-ray Facility at Northwestern University, supported by the International Institute of Nanotechnology (IIN). S. L. acknowledges HPC resources from GENCI-CCRT/CINES (Grant x2014-085106).

\section{Supporting information}

Crystallographic data in cif format for $\mathrm{Ba}_{8} \mathrm{PdU}_{2} \mathrm{Se}_{12}\left(\mathrm{Se}_{2}\right)_{2}$ has been deposited with FIZ Karlsruhe as CSD number 429514. These data may be obtained free of charge by contacting FIZ Karlsruhe at +497247808666 (fax) or crysdata@ fiz-karlsruhe.de (email). 


\section{References}

[1] D. Damien, C.H. de Novion, J. Gal, Solid State Commun. 38 (1981) 437-440.

[2] C.H. de Novion, D. Damien, H. Hubert, J. Solid State Chem. 39 (1981) 360-367.

[3] A.J. Freeman, J.B. Darby Jr., The Actinides: Electronic Structure and Related Properties, vol. 1, 2, Academic Press, New York, 1974.

[4] D.E. Bugaris, J.A. Ibers, Dalton Trans. 39 (2010) 5949-5964.

[5] E. Manos, M.G. Kanatzidis, J.A. Ibers, Actinide Chalcogenide Compounds, in: L.R. Morss, N.M. Edelstein, J. Fuger (Eds.), The Chemistry of the Actinide and Transactinide Elements, 4th ed., Vol. 6, Springer, Dordrecht, The Netherlands, 2010, p. 4005-4078.

[6] K.-S. Choi, R. Patschke, S.J.L. Billinge, M.J. Waner, M. Dantus, M.G. Kanatzidis, J. Am. Chem. Soc. 120 (1998) 10706-10714.

[7] S.A. Sunshine, D.A. Keszler, J.A. Ibers, Acc. Chem. Res. 20 (1987) 395-400.

[8] G.N. Oh, E.S. Choi, J.A. Ibers, Inorg. Chem. 51 (2012) 4224-4230.

[9] D.E. Bugaris, J.A. Ibers, Inorg. Chem. 51 (2012) 661-666.

[10] D.E. Bugaris, D.M. Wells, J.A. Ibers, J. Solid State Chem. 182 (2009) 1017-1020.

[11] F.Q. Huang, K. Mitchell, J.A. Ibers, Inorg. Chem. 40 (2001) 5123-5126.

[12] J. Yao, J.A. Ibers, Z. Anorg. Allg. Chem. 634 (2008) 1645-1647.

[13] C.D. Malliakas, J. Yao, D.M. Wells, G.B. Jin, S. Skanthakumar, E.S. Choi, M. 
Balasubramanian, L. Soderholm, D.E. Ellis, M.G. Kanatzidis, J.A. Ibers, Inorg. Chem. 51 (2012) 6153-6163.

[14] G.N. Oh, E.S. Choi, J. Lu, L.A. Koscielski, M.D. Ward, D.E. Ellis, J.A. Ibers, Inorg. Chem. 51 (2012) 8873-8881.

[15] D.E. Bugaris, E.S. Choi, R. Copping, P.-A. Glans, S.G. Minasian, T. Tyliszczak, S.A. Kozimor, D.K. Shuh, J.A. Ibers, Inorg. Chem. 50 (2011) 6656-6666.

[16] Adel Mesbah, Jai Prakash, Jessica C. Beard, Sébastien Lebègue, Christos D. Malliakas, and James A. Ibers, Unpublished.

[17] A. Mesbah, Lebegue.S, J.M. Klingsporn, W. Stojko, R.P. Van Duyne, J.A. Ibers, J. Solid State Chem. 200 (2013) 349-353.

[18] H.-yi Zeng, J. Yao, J.A. Ibers, J. Solid State Chem. 181 (2008) 552-555.

[19] J.A. Cody, J.A. Ibers, Inorg. Chem. 34 (1995) 3165-3172.

[20] J.-Y. Kim, D.L. Gray, J.A. Ibers, Acta Cryst. Sect. E: Struct. Rep. Online E62 (2006) i124-i125.

[21] M.D. Ward, A. Mesbah, M. Lee, C.D. Malliakas, E.S. Choi, J.A. Ibers, Inorg. Chem. 53 (2014) 7909-7915.

[22] J. Prakash, A. Mesbah, J. Beard, S. Lebègue, C.D. Malliakas, J.A. Ibers, Inorg. Chem. 54 (2015) 3688-3694.

[23] D.E. Bugaris, J.A. Ibers, J. Solid State Chem. 182 (2009) 2587-2590. 
[24] J. Prakash, A. Mesbah, M.D. Ward, S. Lebègue, C.D. Malliakas, M. Lee, E.S. Choi, J.A. Ibers, Inorg. Chem. 54 (2015) 1684-1689.

[25] N. Rodier, V. Tien, Acta Crystallogr. Sect. B: Struct. Crystallogr. Cryst. Chem. 32 (1976) 2705-2707.

[26] A. Mesbah, W. Stojko, S. Lebègue, C.D. Malliakas, L. Frazer, J.A. Ibers, J. Solid State Chem. 221 (2015) 398-404.

[27] A. Mesbah, C.D. Malliakas, S. Lebègue, A.A. Sarjeant, W. Stojko, L.A. Koscielski, J.A. Ibers, Inorg. Chem. 53 (2014) 2899-2903.

[28] D.L. Gray, L.A. Backus, H.-A. Krug von Nidda, S. Skanthakumar, A. Loidl, L. Soderholm, J.A. Ibers, Inorg. Chem. 46 (2007) 6992-6996.

[29] D.E. Bugaris, J.A. Ibers, J. Solid State Chem. 181 (2008) 3189-3193.

[30] A.J.K. Haneveld, F. Jellinek, J. Less-Common Met. 18 (1969) 123-129.

[31] K. Schubert, H. Breimer, W. Burkhardt, E. Günzel, R. Haufler, H.L. Lukas, H. Vetter, J. Wegst, M. Wilkens, Naturwissenschaften 44 (1957) 229-230.

[32] M. F. Mansuetto, S. Jobic, H. P. Ng, J. A. Ibers, Acta Crystallogr. Sect. C: Cryst. Struct. Commun. 49 (1993) 1584-1585.

[33] Bruker APEX2 Version 2009.5-1 Data Collection and Processing Software, Bruker Analytical X-Ray Instruments, Inc., Madison, WI, USA, 2009.

[34] G.M. Sheldrick, SADABS, 2008. Department of Structural Chemistry, University of Göttingen, Göttingen, Germany 
[35] G.M. Sheldrick, Acta Crystallogr. Sect. A: Found. Crystallogr. 64 (2008) 112-122.

[36] L.M. Gelato, E. Parthé, J. Appl. Crystallogr. 20 (1987) 139-143.

[37] A.L. Spek, PLATON, A Multipurpose Crystallographic Tool, 2014. Utrecht University, Utrecht, The Netherlands.

[38] G. Kresse, J. Forthmüller, Comput. Mater. Sci. 6 (1996) 15-50.

[39] G. Kresse, D. Joubert, Phys. Rev. B 59 (1999) 1758-1775.

[40] W. Kohn, L.J. Sham, Phys. Rev. 140 (1965) 1133-1138.

[41] P. Hohenberg, W. Kohn, Phys. Rev. 136 (1964) 864-871.

[42] P.E. Blöchl, Phys. Rev. B 50 (1994) 17953-17979.

[43] J. Heyd, G.E. Scuseria, M. Ernzerhof, J. Phys. Chem. 118 (2003) 8207-8215.

[44] J. Heyd, G.E. Scuseria, M. Ernzerhot, J. Chem. Phys. 124 (2006) 219906-1.

[45] J. Paier, M. Marsman, K. Hummer, G. Kresse, I.C. Gerber, J.G. Angyan, J. Chem. Phys. 124 (2006) 154709.

[46] K.-S. Choi, M.G. Kanatzidis, Chem. Mater. 11 (1999) 2613-2618.

[47] A. Ben Salem, A. Meerschaut, J. Rouxel, C. R. Acad. Sci., Sér. 2299 (1984) 617-619.

[48] Y. Park, M.G. Kanatzidis, Angew. Chem., Int. Ed. Engl. 29 (1990) 914-915. 
[49] W.S. Sheldrick, B. Schaaf, Z. Naturforsch. B: Anorg. Chem. Org. Chem. 49 (1994) 655659.

[50] Y. Park, M.G. Kanatzidis, J. Alloys Compd. 257 (1997) 137-145.

[51] X. Chen, K.J. Dilks, X. Huang, J. Li, Inorg. Chem. 42 (2003) 3723-3727.

[52] D. Topa, E. Makovicky, T. Balic-Zunic, Can. Mineral. 44 (2006) 497-505.

[53] W. Bronger, R. Rennau, D. Schmitz, Z. Anorg. Allg. Chem. 597 (1991) 27-32.

[54] D.A. Keszler, J.A. Ibers, J. Solid State Chem. 52 (1984) 73-79. 
Table 1. Crystallographic data and structure refinement details for $\mathrm{Ba}_{8} \mathrm{PdU}_{2} \mathrm{Se}_{12}\left(\mathrm{Se}_{2}\right)_{2}$

\begin{tabular}{|c|c|}
\hline & $\mathrm{Ba}_{8} \mathrm{PdU}_{2} \mathrm{Se}_{12}\left(\mathrm{Se}_{2}\right)_{2}$ \\
\hline Space group & $D_{2 h}^{12}-P n n m$ \\
\hline$a(\AA)$ & $9.490(1)$ \\
\hline$b(\AA)$ & $12.240(2)$ \\
\hline$c(\AA)$ & $13.780(3)$ \\
\hline$V\left(\AA^{3}\right)$ & $1600.7(6)$ \\
\hline$Z$ & 2 \\
\hline$\rho\left(\mathrm{g} \mathrm{cm}^{-3}\right)$ & 6.109 \\
\hline$\mu\left(\mathrm{mm}^{-1}\right)$ & 38.47 \\
\hline$R(F)^{\mathrm{b}}$ & 0.029 \\
\hline$R_{\mathrm{w}}\left(F_{\mathrm{o}}{ }^{2}\right)^{\mathrm{c}}$ & 0.067 \\
\hline \multicolumn{2}{|c|}{$\lambda=0.71073 \AA, T=100(2) \mathrm{K}}$. \\
\hline \multicolumn{2}{|c|}{${ }^{\mathrm{b}} R(F)=\Sigma|| F_{\mathrm{o}}|-| F_{\mathrm{c}}|| / \Sigma\left|F_{\mathrm{o}}\right|$ for $F_{\mathrm{o}}{ }^{2}>2 \sigma\left(F_{\mathrm{o}}^{2}\right)}$. \\
\hline
\end{tabular}


Table 2. Selected interatomic distances $(\AA)$ for $\mathrm{Ba}_{8} \mathrm{PdU}_{2} \mathrm{Se}_{12}\left(\mathrm{Se}_{2}\right)_{2}$

\begin{tabular}{|c|c|c|c|}
\hline & Distance $(\AA)$ & & Distance $(\AA)$ \\
\hline $\mathrm{U} 1-\mathrm{Se} 1$ & $2.7018(6) \times 2$ & $\mathrm{Ba} 3-\mathrm{Se} 1$ & $3.5834(8) \times 2$ \\
\hline $\mathrm{U} 1-\mathrm{Se} 2$ & $2.6873(3) \times 2$ & $\mathrm{Ba} 3-\mathrm{Se} 2$ & $3.2579(7) \times 2$ \\
\hline $\mathrm{U} 1-\mathrm{Se} 3$ & $2.8023(7) \times 2$ & $\mathrm{Ba} 3-\mathrm{Se} 3$ & $3.5294(8) \times 2$ \\
\hline $\mathrm{Pd} 1-\mathrm{Se} 1$ & $2.5031(6) \times 4$ & $\mathrm{Ba} 3-\mathrm{Se} 4$ & $3.7114(10)$ \\
\hline Ba1-Se1 & $\begin{array}{l}3.4994(8) \\
3.5237(7)\end{array}$ & $\mathrm{Ba} 3-\mathrm{Se} 5$ & $\begin{array}{l}3.1775(9) \\
3.2214(9)\end{array}$ \\
\hline $\mathrm{Ba} 1-\mathrm{Se} 2$ & $\begin{array}{l}3.3912(7) \\
3.4036(7)\end{array}$ & $\mathrm{Pd} 1 \cdots \mathrm{U} 1$ & $3.3693(7) \times 2$ \\
\hline $\mathrm{Ba} 1-\mathrm{Se} 3$ & $\begin{array}{l}3.3085(8) \\
3.3212(8) \\
3.3869(8)\end{array}$ & $\mathrm{U} 1 \cdots \mathrm{U} 1$ & $6.738(1)$ \\
\hline $\mathrm{Ba} 1-\mathrm{Se} 4$ & $3.6711(8)$ & $\mathrm{Se} 4-\mathrm{Se} 4$ & $2.392(2)$ \\
\hline Ba1-Se5 & $3.5499(7)$ & Se5-Se5 & $2.407(1)$ \\
\hline $\mathrm{Ba} 2-\mathrm{Se} 2$ & $\begin{array}{l}3.3803(8) \times 2 \\
3.5617(8) \times 2\end{array}$ & & \\
\hline $\mathrm{Ba} 2-\mathrm{Se} 3$ & $3.5038(8) \times 2$ & & \\
\hline $\mathrm{Ba} 2-\mathrm{Se} 4$ & $\begin{array}{l}3.1625(10) \\
3.2243(9)\end{array}$ & & \\
\hline
\end{tabular}


Table 3: U-Se interactions in some related compounds

\begin{tabular}{lllll}
\hline Compound & Structure & U-Se distances $(\AA)$ & $\begin{array}{l}\text { U Oxidation } \\
\text { State }\end{array}$ & Ref. \\
\hline $\mathrm{Ba}_{8} \mathrm{PdU}_{2} \mathrm{Se}_{12}\left(\mathrm{Se}_{2}\right)_{2}$ & salt-like & $2.6873(3)$ to $2.8023(7)$ & +5 & This work \\
$\mathrm{Tl}_{3} \mathrm{Cu}_{4} \mathrm{USe}_{6}{ }^{\mathrm{a}}$ & Layered & $2.725(2)$ to $2.850(2)$ & +5 & {$[15]$} \\
$\mathrm{Cs}_{2} \mathrm{Pt}_{3} \mathrm{USe}_{6}{ }^{\mathrm{b}}$ & Layered & $2.8354(5)$ to $2.8806(7)$ & +4 & {$[8]$} \\
$\mathrm{Cs}_{2} \mathrm{Pd}_{3} \mathrm{USe}_{6}{ }^{\mathrm{b}}$ & Layered & $2.8353(5)$ to $2.8704(2)$ & +4 & {$[8]$} \\
$\mathrm{Tl}_{2} \mathrm{Ag}_{2} \mathrm{USe}_{4}{ }^{\mathrm{a}}$ & Layered & $2.853(2)$ to $2.881(1)$ & +4 & {$[15]$} \\
$\mathrm{CsCuUSe}_{3}{ }^{\mathrm{a}}$ & Layered & $2.826(1)$ to $2.861(1)$ & +4 & {$[11]$} \\
$\mathrm{Cs}_{2} \mathrm{Hg}_{2} \mathrm{USe}_{5}{ }^{\mathrm{a}}$ & Layered & $2.872(1)$ to 2.902(1) & +4 & {$[10]$} \\
\hline
\end{tabular}

${ }^{\mathrm{a}}$ Octahedral coordination; ${ }^{\mathrm{b}}$ trigonal-prismatic coordination. 


\section{Figure Legends.}

Fig. 1. Crystal structure of $\mathrm{Ba}_{8} \mathrm{PdU}_{2} \mathrm{Se}_{12}\left(\mathrm{Se}_{2}\right)_{2}$ viewed approximately along the $b$-axis.

Fig. 2. Coordination polyhedra of $\mathrm{U}$ and $\mathrm{Pd}$ in $\mathrm{Ba}_{8} \mathrm{PdU}_{2} \mathrm{Se}_{12}\left(\mathrm{Se}_{2}\right)_{2}$.

Fig. 3. Coordination polyhedra of $\mathrm{Ba}$ atoms in $\mathrm{Ba}_{8} \mathrm{PdU}_{2} \mathrm{Se}_{12}\left(\mathrm{Se}_{2}\right)_{2}$. $\mathrm{Ba}-\mathrm{Se}$ interactions are shown as dotted lines.

Fig. 4. (Left) Resistivity as a function of temperature of a $\mathrm{Ba}_{8} \mathrm{PdU}_{2} \mathrm{Se}_{12}\left(\mathrm{Se}_{2}\right)_{2}$ single crystal showing semiconducting behavior. (Right) Arrhenius plot of resistivity with an activation energy of $0.18(1) \mathrm{eV}$.

Fig. 5. Computed total and partial density of states of $\mathrm{Ba}_{8} \mathrm{PdU}_{2} \mathrm{Se}_{12}\left(\mathrm{Se}_{2}\right)_{2}$. 


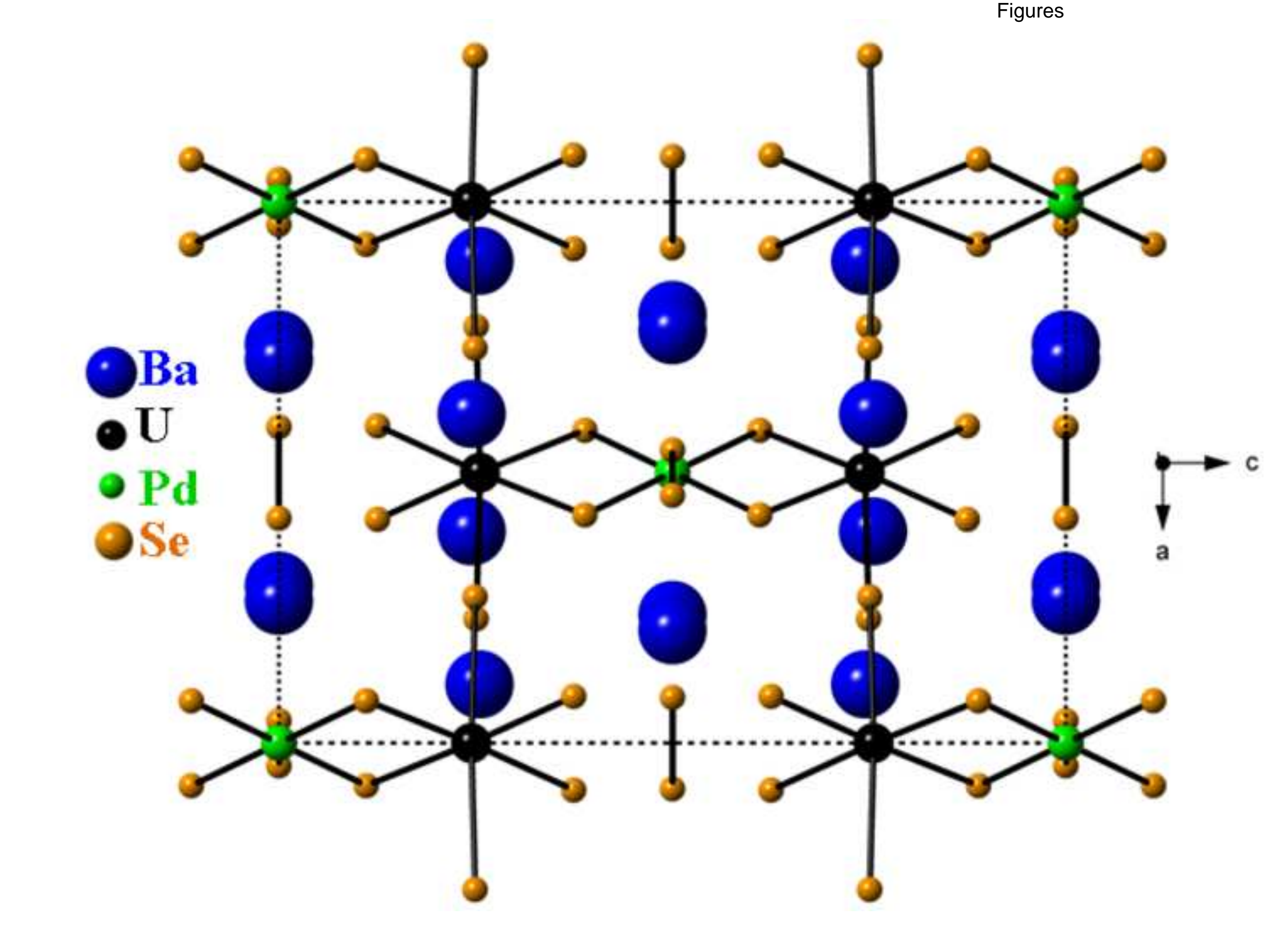

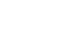

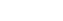

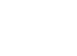


Click here to download high resolution image

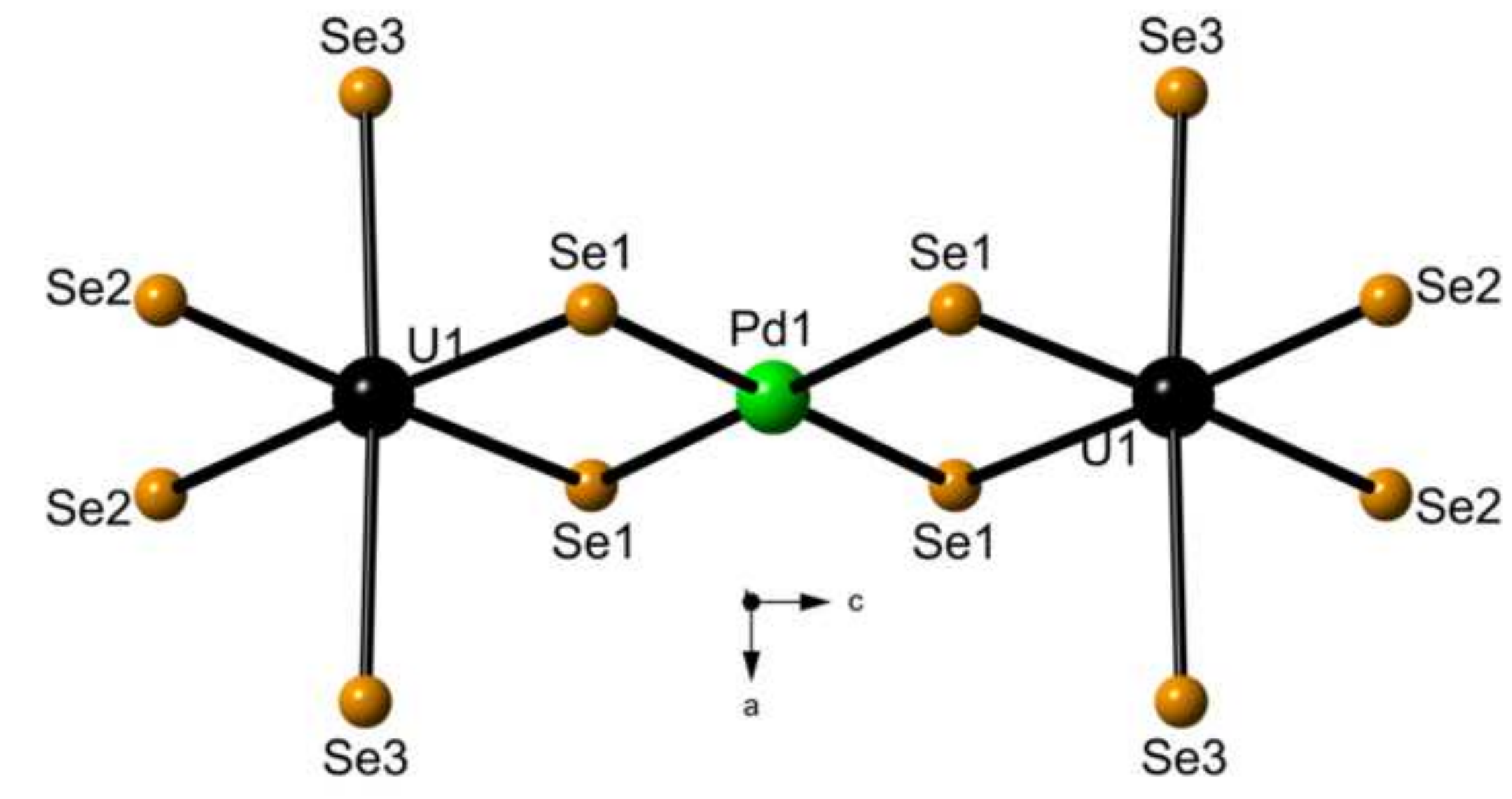



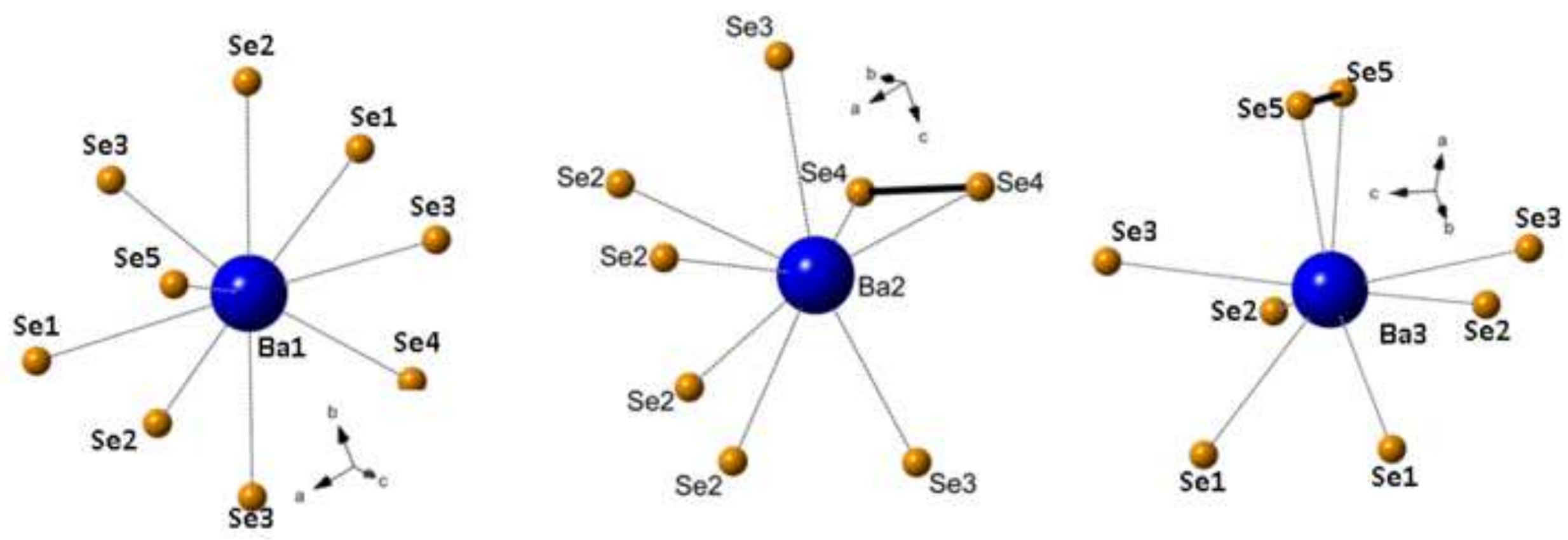

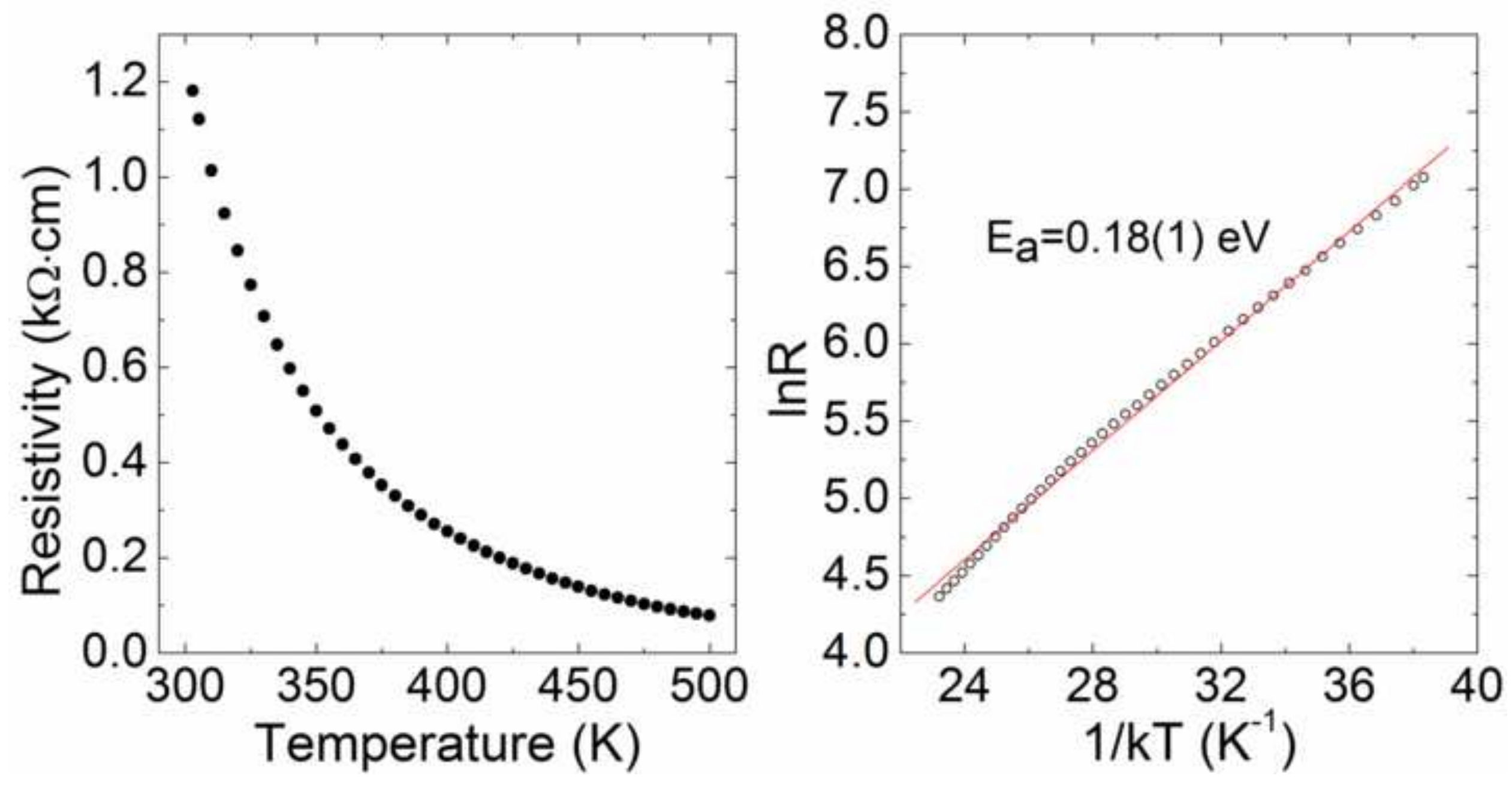
Click here to download high resolution image

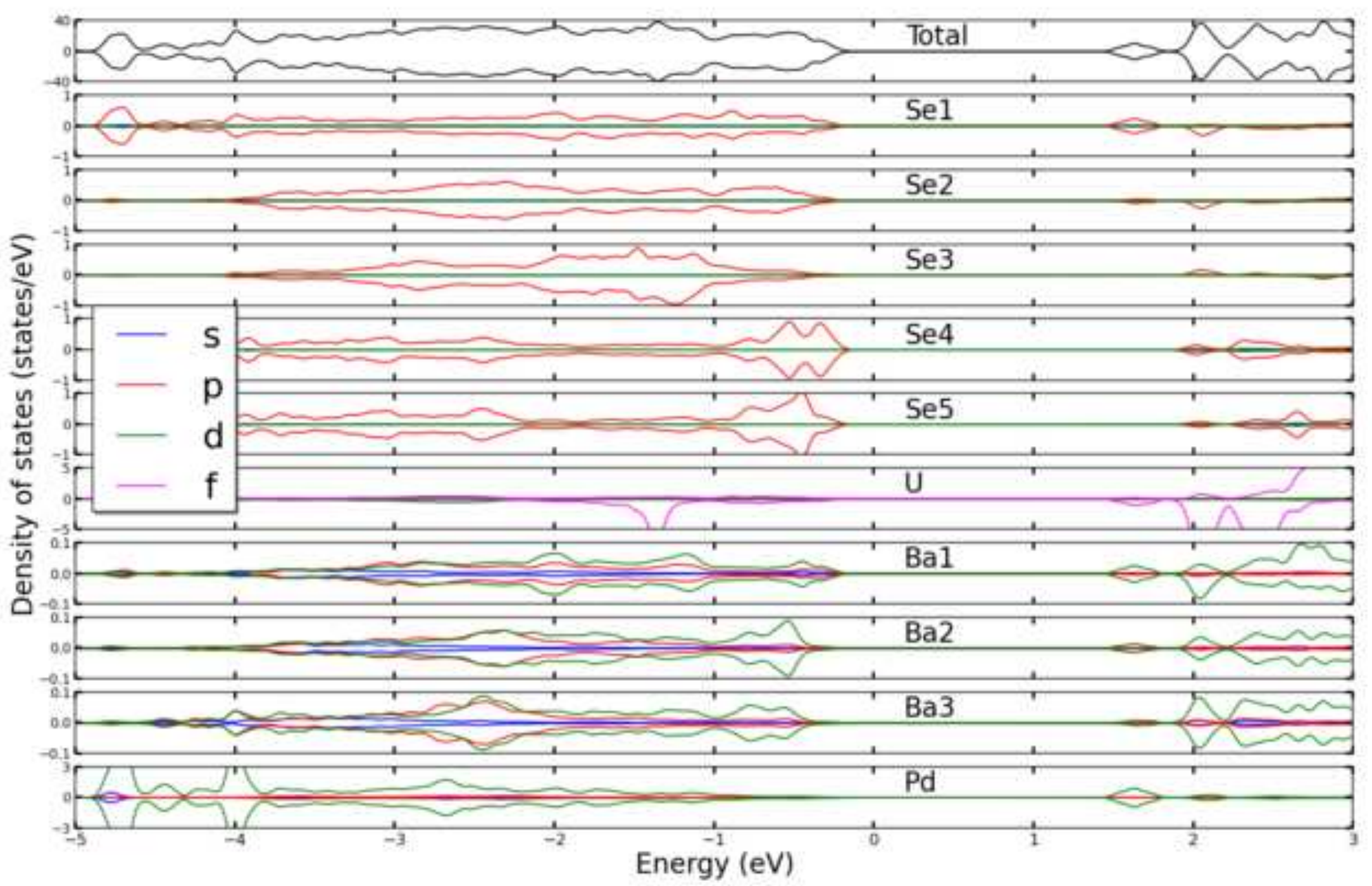




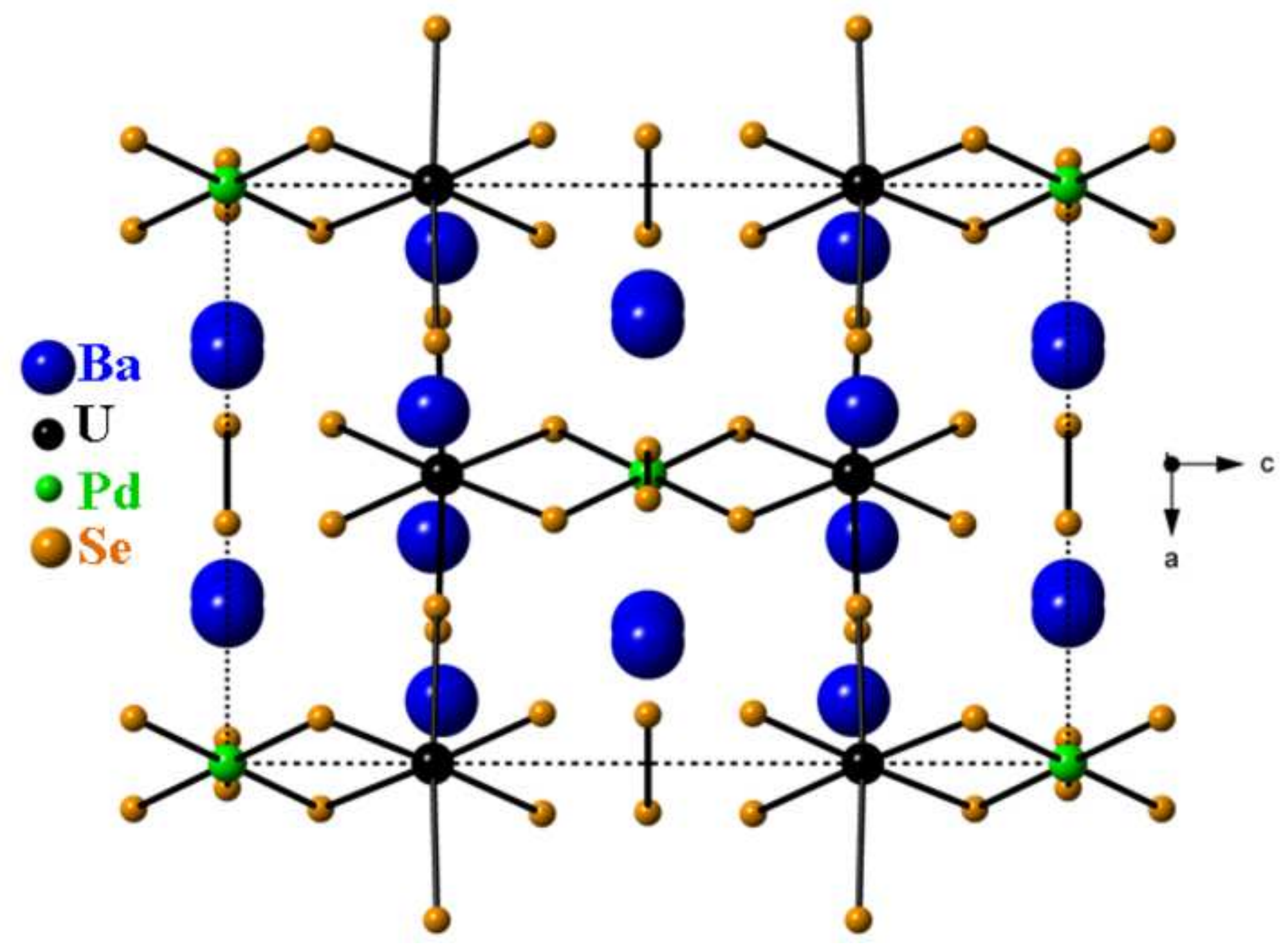

